\title{
Ks. Robert Samsel, Teoria reformacji Stanisława Hozjusza na podstawie jego „Cenzury”, Kraków 2010, 259 s.
}

Książka ks. Samsela dotyczy bardzo ważnego okresu w dziejach Kościoła, który w sposób decydujący wpłynął także na kształt chrześcijaństwa dzisiaj: okresu reformacji. Autor przygląda się reformacji z bardzo szczególnego punktu widzenia, a mianowicie analizując teorię reformacji jednego z najwybitniejszych polskich teologów nowożytnych, Stanisława Hozjusza.

Materiałem źródłowym dla książki ks. Samsela jest praca Stanisława Hozjusza Cenzura albo rozsądek jednego katolika przy prawej a starożytnej wierze stojącego na rozsądek i cenzurę ministrów Tygurskich i Heidelberskich, około nauki przeciw Trójcy Świętej w Polsce niedawno rozsianej. Praca ta była odpowiedzią na książkę Stanisława Sarnickiego O uznaniu Pana Boga wszechmogącego troje kazanie, wydanej w Krakowie w 1564 roku. Analiza pracy kardynała Hozjusza tworzy główny zrąb książki; w trzech kolejnych rozdziałach autor przedstawia poglądy biskupa warmińskiego na teologię różnych poreformacyjnych nurtów chrześcijaństwa. I tak odpowiednio pierwszy rozdział jest polemiką z teologią luterańską, drugi rozdział z teologią kalwińską, trzeci rozdział zawiera polemikę z Braćmi Polskimi.

W pierwszym rozdziale książki autor dokonuje analizy polemiki kardynała Hozjusza z teologią luterańską w dwóch kluczowych punktach sporu: rozumienie autorytetu Pisma Świętego w Kościele i rozumienie Kościoła, eklezjologia. Drugi punkt zawiera oczywiście tak ważne dla sporu katolicko-luterańskiego punkty jak rozumienie Eucharystii i urzędu papieża w Kościele. W pierwszym rozdziale zaznacza się już bardzo wyraźnie, że autorowi nie chodzi tylko o pracę z dziedziny historii teologii, ale poprzez swoje analizy historyczne chce on także wziąć udział $\mathrm{w}$ aktualnych dyskusjach w dziedzinie dialogu ekumenicznego na polu teologii.

Tematem rozdziału drugiego jest hozjuszowska krytyka kalwinizmu. Autor rozpoczyna od bardzo ciekawego wstępu historycznego, który dotyczy w dużej mierze Jana Łaskiego i znaczenia jego działalności dla powstania wspólnot ewangelicko-reformowanych w Polsce. W kontekście działalności Łaskiego i omawiania treści Konfesji Sandomierskiej pojawia się oskarżenie skierowane ze strony wspólnot reformowanych wobec Hozjusza, że ze względu na swoją nieprzejednaną postawę doktrynalną był on przeciwnikiem jedności Kościoła, czyli - używając współczesnego języka - „antyekumenistą". Niewątpliwie autor prowokuje w ten sposób rozważania dotyczące „straconych szans” w katolickiej reakcji antyreformacyjnej.

Trzeci rozdział recenzowanej pracy poświęcony jest rozważaniom na temat Braci Polskich. Za Hozjuszem autor używa metafory architektonicznej, mówiąc, że o ile herezje luterańska i kalwińska doprowadziły do rozebrania „dachu” Kościoła i jego „ścian”, to herezja antytrynitarska doprowadziła do burzenia samych „fundamentów" Kościoła, narażając Braci Polskich zresztą na krytykę i prześladowanie ze strony innych wspólnot protestanckich. Ponieważ sam Hozjusz nie poświęca dużo miejsca w swojej Ocenie doktrynie Braci Polskich, autor znacznie wychodzi tutaj poza tę pracę, przedstawiając historię ruchu polskich antytrynitarzy, jego głównych przedstawicieli i ich poglądy. Autor zwraca uwage na paradoks reformacji, który polega na fakcie, że pragnienie większej wierności Pismu Świętemu i podstawowym źródłom Objawienia oraz chęć odrzucenia historycznych naleciałości i zniekształceń w Kościele katolickim w ruchu antytrynitarzy doprowadziło w gruncie rzeczy do daleko posuniętego akomodacjonizmu z duchem epoki. Ostatecznie chęć radykalnej reformy, która zerwała ze źródłami wiary i z prawdziwym Kościołem, doprowadziła po prostu do upodobnienia się do świata.

Jak wspomniano powyżej, książka ks. Samsela nie ma charakteru rozprawy historycznej, ale jest głosem, który zamierza aktywnie uczestniczyć w dzisiejszej debacie ekumenicznej.Lekturaksiążki 
prowokuje ważne pytania. W dzisiejszym ruchu ekumenicznym nierzadko mówi się o potrzebie „rehabilitacji” twórców reformacji, zwłaszcza Marcina Lutra i Jana Kalwina, a czasem nawet używa się wobec nich określenia „reformatorzy Kościoła”. W jakiej mierze i przy jakich zastrzeżeniach możemy zaakceptować te określenia? W jakiej mierze w świetle analiz przeprowadzonych w pracy wspólnoty protestanckie, zwłaszcza ruch Braci Polskich, mogą być widziane jako przykład zagrożeń akomodacjonizmu Kościoła? Jakie prawdy doktrynalne, podważone przez wspomniane wspólnoty, strzegą Kościół przed takim akomodacjonizmem i upodobnieniem się do świata? Czy i na ile w życiu i polemicznej działalności kardynała Hozjusza możemy dostrzec „stracone szanse" utrzymania jedności chrześcijan w XVI wieku? Z całą pewnością te i inne pytania, które stawia recenzowana książka, jak też sugerowane kierunki poszukiwania odpowiedzi są nie tylko zagadnieniami dotyczącymi historii Kościoła i teologii, ale także dnia dzisiejszego.

Jarosław Kupczak 